\title{
THE IMPACT OF THE STRUCTURE OF THE ACTIVE MASS TO CHANGES IN SELECTED PARAMETERS OF WATER
}

\author{
Robert Nowak ${ }^{1}$ \\ 1 Faculty of Civil Engineering, Environmental and Geodetic Sciences, Koszalin University of Technology, \\ Koszalin, Poland, e-mail: robert.nowak@tu.koszalin.pl
}

Received: 2016.08.16

Accepted: 2016.09.26

Published: 2016.11.01

\begin{abstract}
The paper presents the results from studies upon the influence of chemical structure of filtration masses used for the treatment of groundwater on the values of selected physicochemical parameters of water. The $\mathrm{pH}$ value of treated water and the redox potential are important in process the oxidation of iron and manganese compounds. These values may change as a result of water contact with filter materials. The value of zeta potential of filtration masses characterizing the surface charge of particles and their affinity to counter-ions, is also important. The study tested masses of different chemical structure, i.e. manganese ores and de-acidifying masses. Experiments were carried out at two different $\mathrm{pH}$ values of the model water. The results showed that the filtration masses affected the water quality and water treatment processes, and the type and magnitude of changes in physicochemical parameters are closely related to, among others, the chemical structure of the filter bed.
\end{abstract}

Keywords: chemical structure, active mass, water.

\section{INTRODUCTION}

In the course of many processes and phenomena occurring during water and sewage treatment, oxidation and reduction reactions are extremely important. Knowledge of the physicochemical parameters of water, such as $\mathrm{pH}$ or redox potential (ORP), allows to specify, among others, the oxidation state of ions in water or the existence of certain chemical reactions. For example, corrosion of materials of the water supply system, oxidation of iron and manganese, nitrification and disinfection are described or depended on the redox reactions.

The redox conditions in water supply systems may be significantly different, from virtually anaerobic to aerobic. Therefore, in various locations of the water treatment and distribution system, speciation may have a wide range, depending on the water reaction and redox conditions (James et. al. 2014). Both water reaction and redox potential values are easily changing as a result of water contact with the outside environment. In waters of the higher potential, the redox system has stronger oxidizing properties. Low level of redox potential causes the ions present in water, e.g. iron and manganese, remain in the low oxidation state. The ORP values for different redox systems allow to predict the direction of redox reaction, and choose the most suitable oxidant or reducer (Drobnik \& Latour 2003).

Performing the ORP measurements in the treated water can be applied as a tool for process control and pollution index of a distribution system (Peiffer 2000). Hovewer, the ORP measurements, mostly improperly conducted and interpreted, are rarely used in the water supply and treatment industry. In the case of natural waters, the ORP measurement accuracy is usually much lower. Under certain conditions, measurements of redox potential in such waters may not even be possible. The causes of problems may be, among others, slow kinetics, mixed potentials, or damaged electrode (Peiffer 2000). The value of redox potential of a single reaction under equilibrium conditions can also be determined theoretically (calculated), but the activity of reacting speciation must be known. However, the use of such 
an approach in studies on natural or underground water is limited, which is emphasized by the author of the present paper (Dobrzyński 2010). He points out two main reasons hindering the water as a whole in achieving the state of equilibrium. These are: the co-existence of multiple pairs of redox speciation in natural waters and the fact that they very rarely remain in redox equilibrium. Up-to-date studies (Appelo \& Postma 2005) confirm that in the absence of balance, simultaneously redox speciation, typical for different environments, e.g. dissolved oxygen with hydrogen sulfide, methane, or iron ion (II), can occur.

In comparable conditions, oxidation of $\mathrm{Mn}$ (II) ions present in water causes more problems than $\mathrm{Fe}$ (II), and it is also difficult in terms of energy (Morgan 2000). Manganese solubility increases in an acidic environment and under anaerobic conditions. In neutral conditions, the redox potential has a stronger impact on the mobility of manganese than $\mathrm{pH}$ (Nadaska et al. 2010). Under aerobic conditions (shallow aquifers and surface water), manganese concentrations in water is usually low and most often does not reach the limits of detection. This is due to the fact that under aerobic conditions, manganese is present in the oxidized form, which is highly insoluble. With the water infiltration into deeper aquifers, the water and soil environment becomes more anaerobic. Under such conditions, manganese is released from minerals and is reduced to soluble form $\mathrm{Mn}$ (II). For these reasons, much higher concentrations of manganese are determined in deep waters than in surface water or shallow groundwater (Nadaska et al. 2010).

The active filtration masses are used in groundwater treatment technology. These are manganese ores, alkalizing materials or natural minerals modified by introducing to their structure manganese cations. The process of iron and manganese removal from water with the participation of alkalizing materials can be effectively carried out even in the aquifer. The authors of the present work (Biedron et al. 2013) concluded that the effective removal of iron and manganese from infiltrated water is determined by the possibility of $\mathrm{pH}$ value and redox potential of the aquifer corrections. As a result of enrichment of rock-ground environment by layers of alkalizing materials, binding of aggressive carbon dioxide can be achieved. In such environment, oxidation of $\mathrm{Fe}$ (II) to $\mathrm{Fe}$ (III) occurs due to chemistry or biochemistry, and generated hardly-soluble iron (III) compounds are retained on porous materials. The contact of ground water with alkalizing material results in elevating the $\mathrm{pH}$ value of water and its basic alkalinity, while decreasing the aggressiveness of carbonic acid in water.

The use of active masses allows the manganese removal from water without the need for an oxidant use or alkalization of water (Ormanci et al. 2013, Piispanen \& Sallanko 2010). The efficiency of oxidation and removal of manganese from water due to its interaction with the surface of the filtration bed depends on many factors (Skoczko et al. 2016, Nowak 2013, Barlokova \& Ilavsky 2010). These include, among others, the chemical structure of deposit, its porosity, as well as the grain size of deposit or structure of their surface (size and distribution of pores). During filtration, chemical, physicochemical, and biological processes run on such deposits (Nowak \& Anielak 2002, Jeż-Walkowiak et al. 2011). For physicochemical processes, in addition to the composition of water, the properties of the filter material are very important, including among others, the porosity, surface nature, and adsorption capacity. Another variable that characterizes the physicochemical properties of the filtration masses is electro-kinetic potential. The value of this potential allows to determine the affinity of their surface to ions present in the treated water, thus including manganese cations. The value of the potential indirectly determines the catalytic properties of tested masses that increase along with the increase of its absolute value (Anielak 1998). The final effect of water purification is affected by all of these factors. The author (Scott 1991) reported that the surfaces of manganese oxides can be oxidants for many reduced chemical compounds. Removal of manganese from groundwater may take place by means of adsorption and formation of Mn oxides coating on the surface of filtration media. However, factors affecting the formation of such coatings have not been fully recognized. In addition, the mechanism of manganese removal from water on active masses is not completely understood (Nowak 2013). The relationships between electro-kinetic potential of given beds and the ability to remove manganese from water, interactions between components of treated water or other relationships between the composition of water and the course of manganese oxidation, are unknown. Among others, for these reasons, removal of iron and manganese from water is not always effective. 
Subsequent parts of the work present and discuss the results of research, defining the size and direction of changes in the selected physicochemical parameters of the model water as a result of its contact with filtration masses of different chemical structure.

\section{MATERIAL AND METHODS}

The study was conducted using two commercially available active masses: G-1 and Hydrocleanit. The G-1 mass is a manganese ore comprising more than $75 \%$ of $\mathrm{MnO}_{2}$. This mass is produced according to Polish technology by means of a special manganese ore processing. Share of the mass in the total volume of the filter fill may range from $30 \%$ to $100 \%$ (manufacturer's recommendations). When treating the water using G-1 mass, water alkalization is not provided.

Hydrocleanit mass is characterized by a different chemical structure. It consists mainly of magnesium and calcium oxides. During the water treatment, height of the bed should be controlled and, if necessary, supplemented, because the mass is consumed during operation. Hydrocleanit is sensitive to very low water $\mathrm{pH}$, and at $\mathrm{pH}$ values below 2 it is dissolved.

Basic physical parameters of studied active masses are presented in Table 1.

The aim of the study was to determine the influence of chemical structure of the active masses on values of selected physicochemical parameters of water containing manganese ions. Studies were carried out under static conditions at two values of the initial water $\mathrm{pH}(\mathrm{pH} 7$ and 9.5). Four different manganese concentrations in model water were accepted: $0.2,1.0,2.0$, and 5.0 $\mathrm{mg} \mathrm{Mn} / \mathrm{L}$. The scope of tests also included determination of the effect of iron ions presence in water. Iron concentration was $10 \mathrm{mg} \mathrm{Fe} / \mathrm{L}$. Temperature of solutions during testing was stable and amounted to approximately $25^{\circ} \mathrm{C}$. Changes in physicochemical parameters of water were determined by measuring the redox potential and

Table 1. Selected physical properties of the active masses (based on the producers)

\begin{tabular}{|l|l|l|}
\hline \multicolumn{1}{|c|}{ Parameter } & \multicolumn{1}{c|}{ G-1 } & Hydrocleanit \\
\hline Colour & $\begin{array}{l}\text { black and } \\
\text { brown }\end{array}$ & white \\
\hline Grain size $(\mathrm{mm})$ & $1 \div 3$ & $0.5 \div 2,2 \div 4,4 \div 7$ \\
\hline Bulk density $\left(\mathrm{T} / \mathrm{m}^{3}\right)$ & 2.0 & $1.5 \div 2.4$ \\
\hline
\end{tabular}

$\mathrm{pH}$ of model solution before and after contact of water with active masses.

Redox reactions, like all other chemical transformations, depend largely on the composition and concentration of a solution. For these reasons, in order to eliminate the impact of other factors than assumed ones, the tests were conducted using distilled water. In order to prepare the model water, following solutions were prepared: $\mathrm{MnSO}_{4} \cdot \mathrm{H}_{2} \mathrm{O}$ at the concentration of $0.1 \mathrm{~g} / \mathrm{L}$, and $\mathrm{FeSO}_{4} \cdot \mathrm{H}_{2} \mathrm{O}$ at the concentration of $10 \mathrm{~g} / \mathrm{L}$. The required manganese concentration was obtained by introducing the appropriate amount of manganese sulfate into a graduated cylinder and adjusting with water to $200 \mathrm{ml}$ in the sample. The $\mathrm{pH}$ adjustment was carried out using $\mathrm{NaOH}$. The pH-meter CX-551 (Adwa company) was used for measurements and the redox potential was measured by applying plastic electrode. Active G-1 mass and Hydrocleanit were added into the water $(1 \mathrm{~g} / 200 \mathrm{ml}$ each time). In order to achieve a fine material, particles of tested masses were ground in a bead mill. The samples prepared in such way were placed in a shaker LS (POL-EKO) and shaken for $15 \mathrm{~min}$ at the speed of $230 \mathrm{rpm}$. Finally, samples were centrifuged in MPW-360 centrifuge (producer Centrifuge) for $15 \mathrm{~min}$ at $3800 \mathrm{rpm}$.

In physicochemical processes, the zeta potential value is a measure of the surface charge of particles and their affinity to counter ions (Anielak 1998). Therefore, the value of zeta potential for the filter masses, is important. Zeta electrokinetic potential measurements were carried out in 10 runs. Each of them consisted of electrophoretic mobility measurement of 20 particles. The value of the zeta potential for a given particle was calculated according to the Smoluchowski formula. Statistical zeta potential was determined on the basis of achieved values occurrence.

\section{RESULTS AND DISCUSSION}

In the first part of the studies, zeta potential values were determined for the individual masses. The test results are shown in Table 2 and Figure 1.

Values in Table 2 are the arithmetic mean from two separate determinations of zeta potential (two graphs in Figure 1 for each of the active masses).

The results from tests showed that there are differences in the values of electro-kinetic potential for particles of the studied filtration masses. A 
Table 2. Zeta potential values for particles of masses G-1 and Hydrocleanit along with conditions of measurement

\begin{tabular}{|l|c|c|}
\hline \multicolumn{1}{|c|}{ Parameter } & G-1 & Hydrocleanit \\
\hline Zeta potential, $\mathrm{mV}$ & -9.27 & 4.88 \\
\hline Particle size, $\mathrm{nm}$ & 1195 & 2348 \\
\hline Concentration, $\mathrm{mg} / \mathrm{L}$ & 20 & 103 \\
\hline $\mathrm{pH}$ & 6.10 & 10.93 \\
\hline Temperature, ${ }^{\circ} \mathrm{C}$ & 25 & 25 \\
\hline Electric filed intensity, $\mathrm{V} / \mathrm{cm}$ & 14.4 & 15.8 \\
\hline
\end{tabular}

higher absolute value of zeta potential characterizes particles of G-1. At a sample concentration of $20 \mathrm{mg} / \mathrm{L}$, the potential averaged $-9.27 \mathrm{mV}$. Lower potential value was determined for the mass Hydrocleanit, i.e. $4.88 \mathrm{mV}$ at $\mathrm{pH} 10.93$. Particles of both masses did not show the dispersion stability. However, a greater ability to coagulate was shown by particles of Hydrocleanit mass. This is indicated by twice as high, compared to the G-1 mass, particle diameter, despite of their classification under equal conditions for both masses.

On the basis of the obtained results it is clear that Hydrocleanit mass particles exhibit lower catalytic properties than G-1 particles. A positive sign of the zeta potential proves that adsorption of cations on the surface of Hydrocleanit mass particles should be difficult. This means that the mechanism of a given mass action during the manganese removal from water is different. Chemical structure of mass Hydrocleanit shows that it consists in water alkalizing.

The results from test determining the influence of active masses G-1 and Hydrocleanit contact on redox potential value of a model solution are presented below. The presence of manganese ions in water (tested concentrations: $0.2,1,2$, and $5 \mathrm{mg} \mathrm{Mn} / \mathrm{L}$ ) as well as the presence (or absence) of iron ions (10 mg Fe/L) was taken into account.
The data include results from studies for solutions characterized by neutral $(\mathrm{pH}=7)$ and alkaline reaction $(\mathrm{pH}=9.5)$. Changes in potential values of model water due to its contact with particles of G-1 active mass are presented in Figure 2.

The study showed that there was a significant increase in the redox potential of model water as a result of its contact with the G-1 active mass. Such relationship was found both at neutral and alkaline $\mathrm{pH}$ of test solution. The observed changes indicated an increase in the oxidizing properties of the solution, which in the case of G-1 mass application for water treatment would mean better results of manganese removal.

It should be noted that during the model water contact with G-1 mass, the level of redox potential was strongly dependent on the water $\mathrm{pH}$ value. At $\mathrm{pH}$ 9,5 final potential found in the solution was much lower than the one characterized by neutral reaction.

Iron ions may aid or impede the oxidation of manganese. In the case of G-1 active mass, the presence of iron in model water affected the value of solution redox potential, and the parameter determining the change direction was $\mathrm{pH}$ of the model solution. At neutral $\mathrm{pH}$ of a solution containing manganese besides iron ions, there was a higher potential growth than in water that did not contain Fe. An inverse relationship was recorded in alkaline water. Negative influence of iron is associated with lower redox potential for the system $\mathrm{Fe}^{2+} / \mathrm{Fe}^{3+}$ than for $\mathrm{Mn}^{2+} / \mathrm{Mn}^{4+}$ and occurs when iron is present in water in a dissolved form (bivalent ions). Under such conditions, manganese oxidation takes place after prior iron oxidation. Other dependencies occur in the case of iron presence in non-dissolved form (as hydroxides). Therefore, iron may be an additional surface, onto which manganese ions could be adsorbed (Nawrocki 2010).
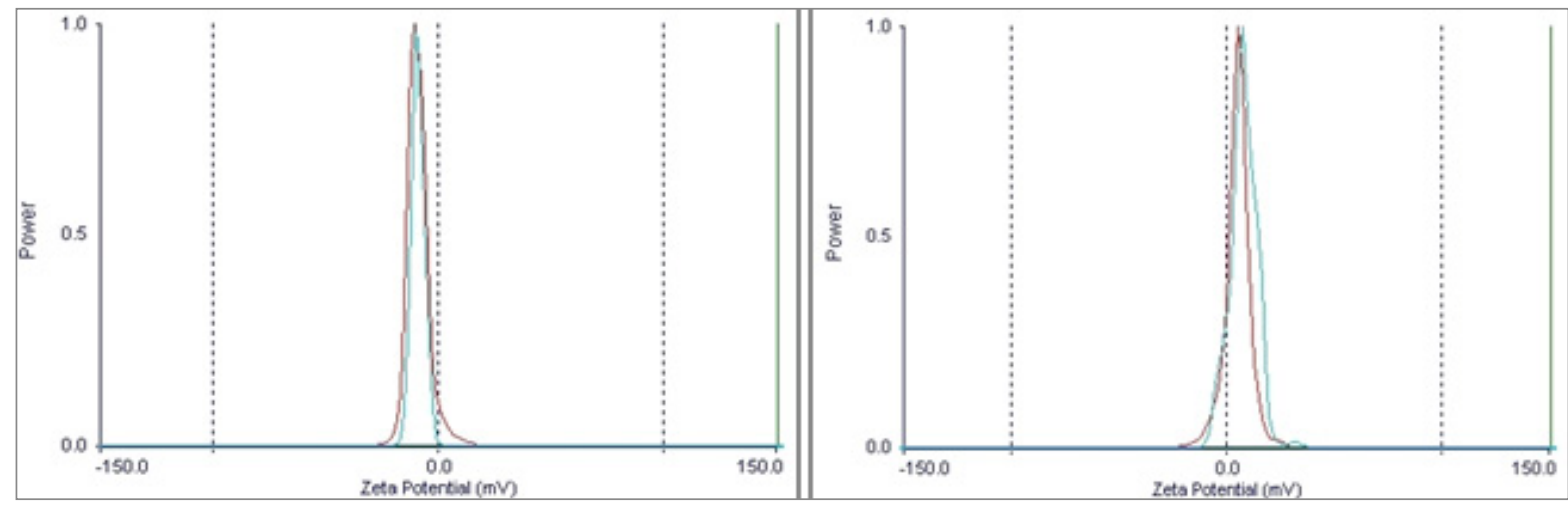

Figure 1. Electro-kinetic potential for particles of mass of G-1 (left) and Hydrocleanit (right) 


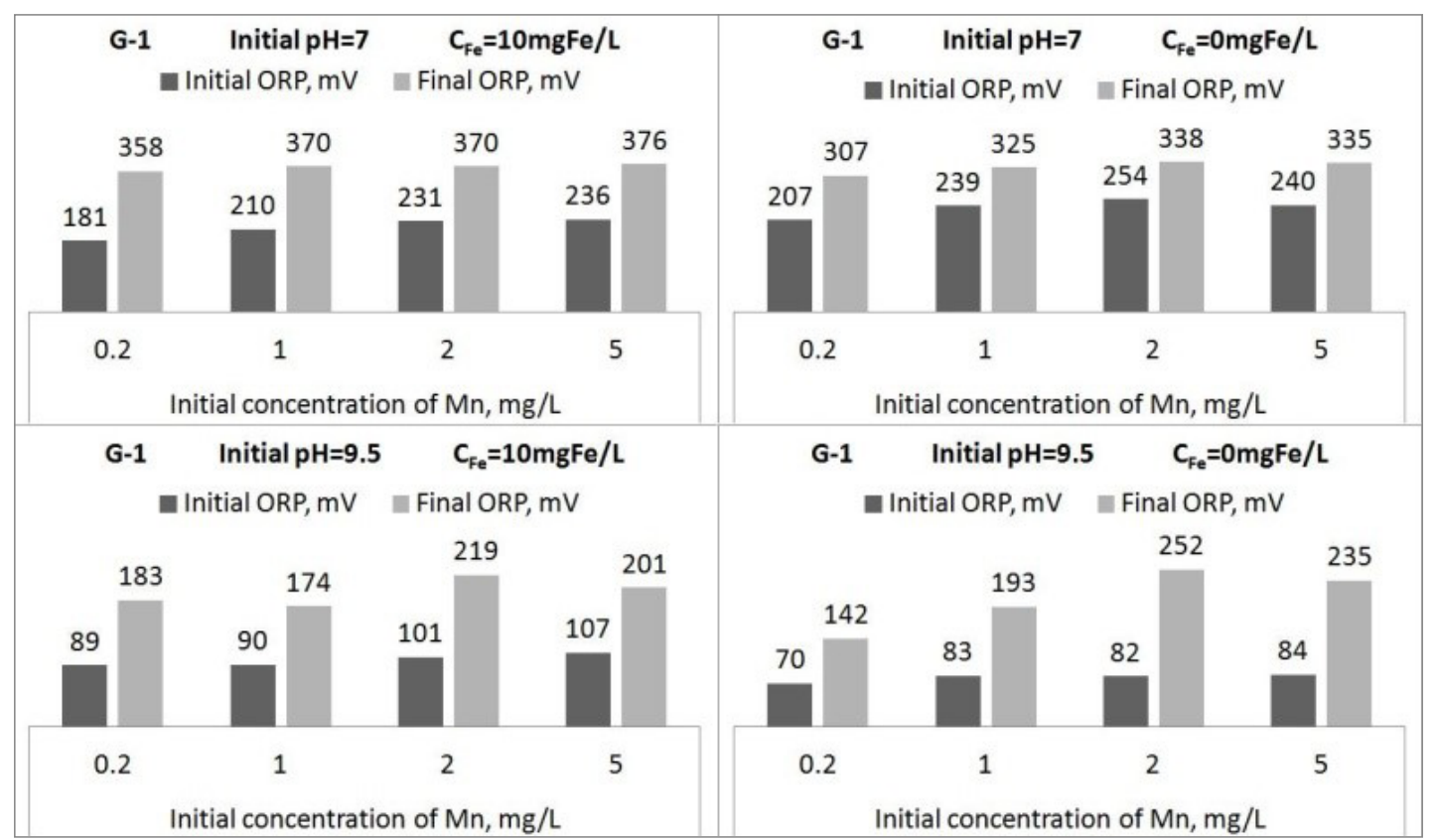

Figure 2. Impact of water reaction, manganese concentration, and iron ions presence on redox potential values during water contact with G-1 active mass

Changes in model water $\mathrm{pH}$ values observed during its contact with G-1 mass (Tables 3 and 4) were also associated with the composition of the model water. The effect on the final $\mathrm{pH}$ of water was exerted, in addition to the initial reaction, by manganese concentration and iron ions presence.

The final $\mathrm{pH}$ of water was stable, though lower than initial one ( $\mathrm{pH}$ about $6.1 \div 6.2$ ) in the neutral solution and in the presence of iron ions. In the absence of iron ions in water, a continuous trend of decreasing the water $\mathrm{pH}$ with increasing concentrations of manganese (up to $\mathrm{pH} 6.71$ at 5 $\mathrm{mg} \mathrm{Mn} / \mathrm{L}$ ) was recorded.

In alkaline reaction, the contact of solution with G-1 mass resulted in a decrease in water $\mathrm{pH}$ value. Such tendency was present for all tested manganese

Table 3. The $\mathrm{pH}$ values of water after contact with active $\mathrm{G}-1$ mass. Initial $\mathrm{pH}=7$

\begin{tabular}{|l|c|c|c|c|}
\hline \multicolumn{1}{|c|}{ Parameter } & \multicolumn{4}{|c|}{ Initial concentration of $\mathrm{Mn}, \mathrm{mg} / \mathrm{L}$} \\
\hline & 0.2 & 1.0 & 2.0 & 5.0 \\
\hline Final pH (with Fe) & 6.22 & 6.24 & 6.09 & 6.11 \\
\hline Final pH (no Fe) & 7.19 & 7.01 & 6.79 & 6.71 \\
\hline
\end{tabular}

Table 4. The $\mathrm{pH}$ values of water after contact with $\mathrm{G}-1$ active mass. Initial $\mathrm{pH}=9.5$.

\begin{tabular}{|l|c|c|c|c|}
\hline \multicolumn{1}{|c|}{ Parameter } & \multicolumn{4}{|c|}{ Initial concentration of Mn, mg/L } \\
\hline & 0.2 & 1.0 & 2.0 & 5.0 \\
\hline Final pH (with Fe) & 8.64 & 8.81 & 8.12 & 8.21 \\
\hline Final pH (no Fe) & 8.91 & 8.74 & 8.12 & 7.64 \\
\hline
\end{tabular}

concentrations in water. More intensive changes were observed in water containing iron ions. Figure 3 presents redox potential values for model water resulting from its contact with particles of Hydrocleanit active mass.

The study results showed that both in the solution with the initial $\mathrm{pH}=7$, and in the alkaline solution ( $\mathrm{pH}$ 9.5), the redox potential decreased as a result of contact with the Hydrocleanit mass. This is a distinct trend in relation to that observed for the G-1 mass. The recorded decrease in the potential value was lower at higher manganese concentrations in water. This relation relates primarily to a neutral solution.

Comparison of the relevant data contained in Figure 3 clearly shows the dependence of the redox potential on the solution $\mathrm{pH}$. The measured values of potential and the nature of the solution oxidizing properties changes as a result of its contact with mass Hydrocleanit are much lower at $\mathrm{pH} 9.5$ than at $\mathrm{pH}=7$.

The $\mathrm{pH}$ of the solution was changing due to the contact with Hydrocleanit mass (Tables 5 and 6). The amount of variations was strongly dependent on the initial $\mathrm{pH}$ value of water. When the $\mathrm{pH}$ of the model water was neutral, the alkalizing effect of the active mass was observed, which resulted in an increase in $\mathrm{pH}$ of the final solution. At the same time, the intensity of water $\mathrm{pH}$ value changes decreased along with increasing manganese concentration (however, it remained above the initial 


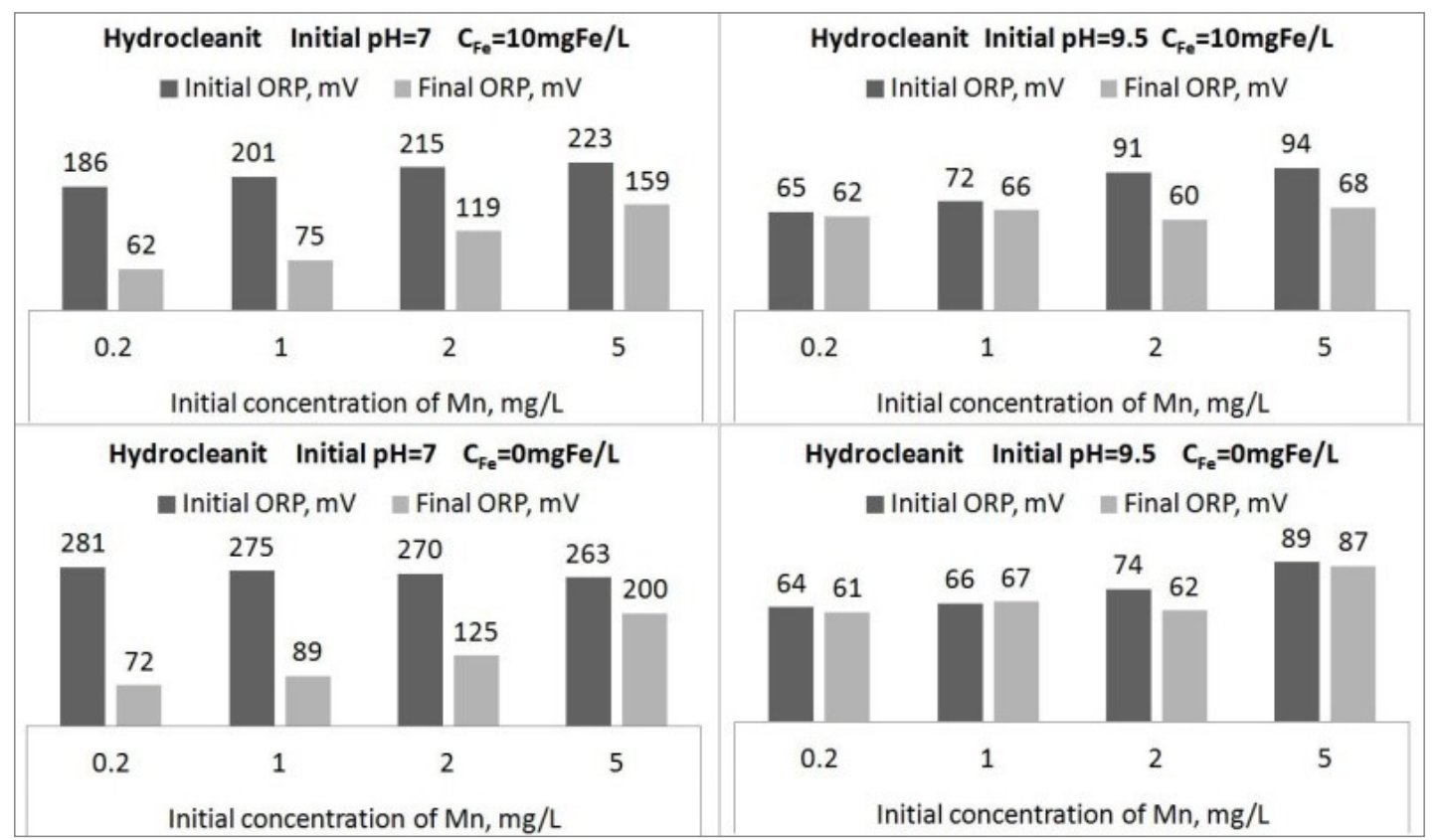

Figure 3. Impact of water reaction, manganese concentration, and iron ions presence on redox potential values during water contact with Hydrocleanit active mass

Table 5. The $\mathrm{pH}$ values of water after contact with Hydrocleanit active mass. Initial $\mathrm{pH}=7$.

\begin{tabular}{|l|c|c|c|c|}
\hline \multicolumn{1}{|c|}{ Parameter } & \multicolumn{4}{|c|}{ Initial concentration of $\mathrm{Mn}, \mathrm{mg} / \mathrm{L}$} \\
\hline & 0.2 & 1.0 & 2.0 & 5.0 \\
\hline Final pH (with Fe) & 9.84 & 9.61 & 8.77 & 8.21 \\
\hline Final pH (no Fe) & 9.81 & 9.46 & 8.60 & 7.78 \\
\hline
\end{tabular}

$\mathrm{pH}$ up to $5 \mathrm{mg} \mathrm{Mn} / \mathrm{l})$. This tendency was more pronounced in water containing no iron ions (Table 5).

For a solution with an initial pH 9.5 (Table 6), the values of a final reaction were slightly higher (about 9.8 $\div 9.9$ ) and stable, regardless of manganese concentration and iron ions presence in water.

In order to compare the impact of the active masses on changes in redox potential of the solution, Figures 4 and 5 summarize the test results obtained for the mass G-1 and Hydrocleanit. Figure 4 shows the relationships obtained during tests for the model solutions containing iron ions. Figure 5 illustrates the redox potential changes taking place as a result of the active masses contact with the model solution, in which iron ions were absent.

Values of the redox potential presented in figures 4 and 5 clearly confirmed the fact that the tested active masses influenced the physicochemical properties of water in different ways. In the case of G-1 mass under all processing conditions (various manganese concentrations, presence and absence of iron ions, neutral and alkaline reaction), a significant increase in the redox po-
Table 6. The $\mathrm{pH}$ values of water after contact with Hydrocleanit active mass. Initial $\mathrm{pH}=9.5$

\begin{tabular}{|l|c|c|c|c|}
\hline \multicolumn{1}{|c|}{ Parameter } & \multicolumn{4}{|c|}{ Initial concentration of $\mathrm{Mn}, \mathrm{mg} / \mathrm{L}$} \\
\hline & 0.2 & 1.0 & 2.0 & 5.0 \\
\hline Final pH (with Fe) & 9.79 & 9.84 & 9.92 & 9.91 \\
\hline Final pH (no Fe) & 9.89 & 9.93 & 9.96 & 9.97 \\
\hline
\end{tabular}

tential of the solution resulting from the contact of water with particles of a given mass, was recorded. Potential values were higher along with increasing manganese concentrations in water. The greatest changes were observed in the neutral environment. The impact of Hydrocleanit mass on oxidizing properties of the model solution was different. Regardless of the model solution composition, contact with particles of that mass not only did not increase the solution potential, but in virtually all cases resulted in lowering its value. This relationship was particularly evident in the neutral reaction.

In the case of Hydrocleanit mass, the presence of iron ions appeared to be especially important for changes intensity of the redox potential in the model water characterized by an alkaline reaction (Figure 5). Under such conditions, virtually no changes in the redox potential of the solution upon contact with a given mass particles, were recorded. At the same time, under similar processing conditions, the G-1 mass significantly increased the level of water potential. 


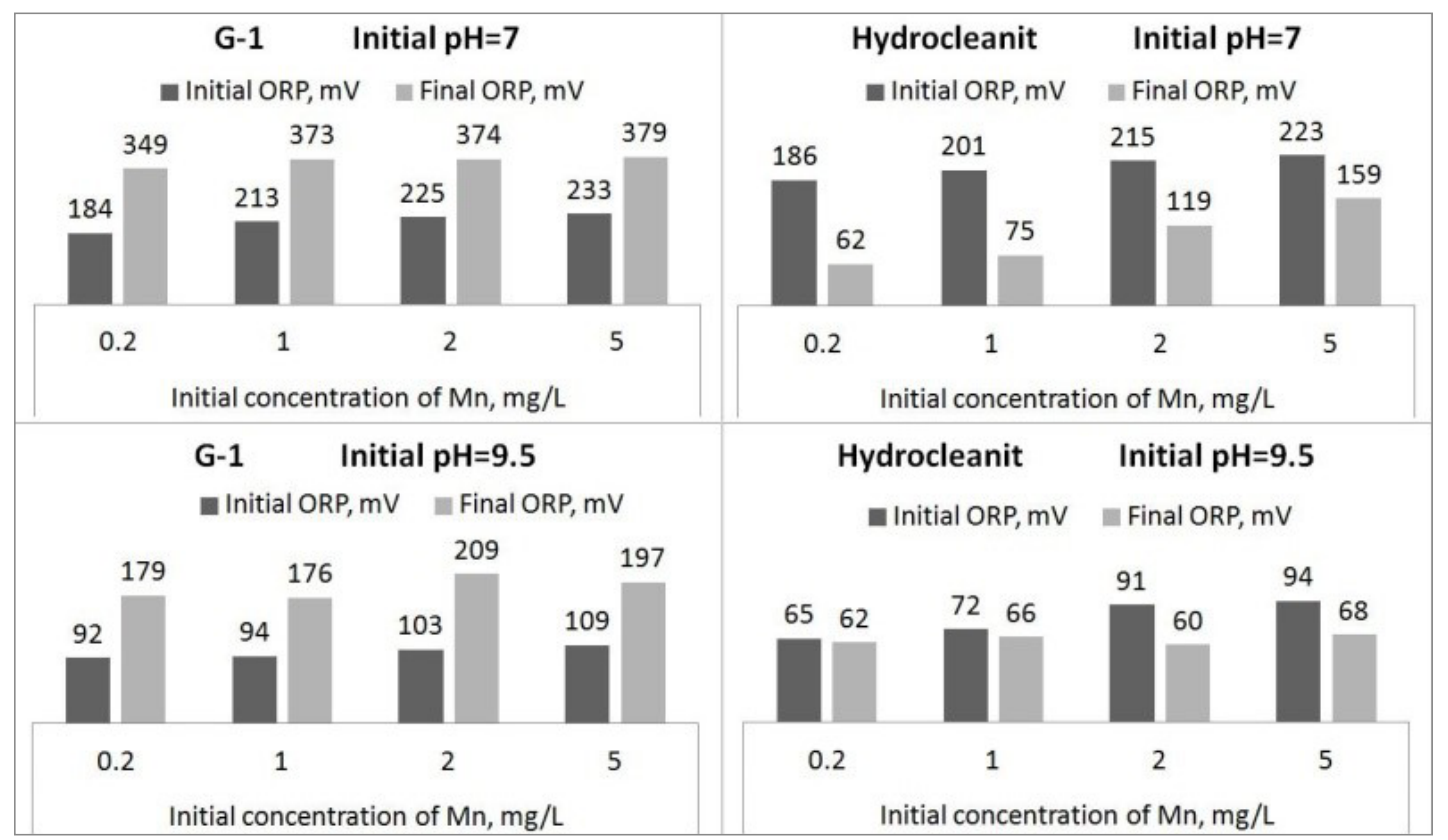

Figure 4. Influence of active mass type and water reaction ( $\mathrm{pH} 7$ and 9.5) on redox potential values during manganese removal from water in the presence of iron ions $(10 \mathrm{mg} / \mathrm{L})$

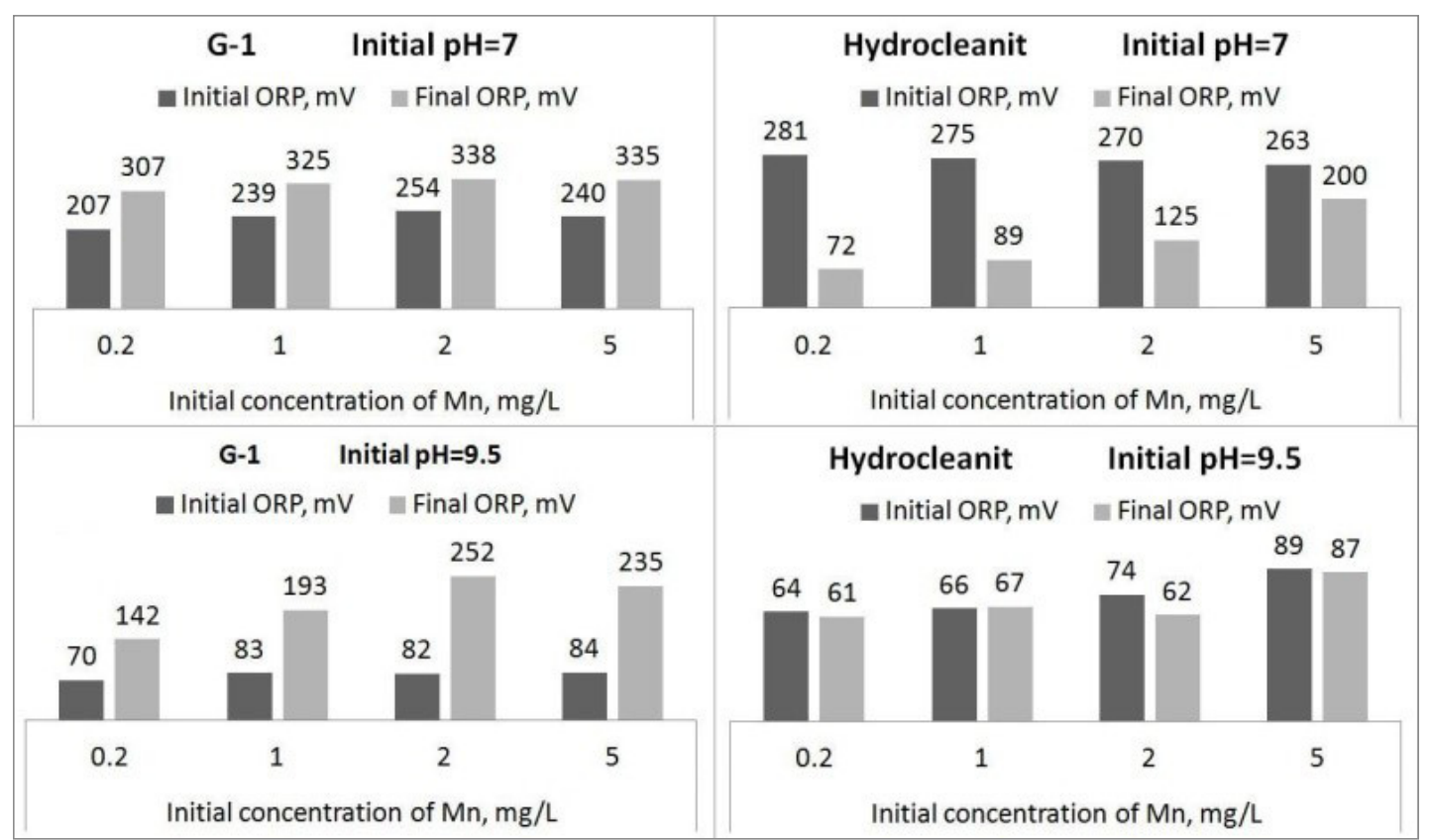

Figure 5. Influence of active mass type and water reaction ( $\mathrm{pH} 7$ and 9.5) on redox potential values during manganese removal from water in the absence of iron ions

\section{CONCLUSIONS}

1. Filtration masses affect the water quality and its treatment processes. The intensity and direction of changes occurring in water during manganese and iron removal with the use of active masses, largely depend on their chemical structure.
2. It was also a clear relationship between the values of physicochemical parameters, such as zeta potential of active masses particles, redox potential, and $\mathrm{pH}$ value of the model solution vs. the course of water treatment processes in the presence of filtration masses.

3. In the case of active masses, the structure of which includes insoluble manganese oxides 
(G-1 mass), size and negative sign of zeta potential indicate a catalytic action of such mass during the manganese removal out of the water. These findings confirmed the results of water redox potential measurements. The redox potential of water increased through the contact with G-1 mass, which has been observed under all test conditions. The increase in the potential value proved the stronger oxidizing properties of the tested solutions. It must therefore be assumed that the process of manganese removal in the presence of G-1 mass will run effectively. At low values of water redox potential, iron or manganese ions present would remain at a low oxidation state, i.e. dissolved in the water. Their removal by means of catalytic oxidation would be difficult under such conditions.

4. A positive sign of zeta potential value found for the Hydrocleanit mass suggests a different mechanism of manganese removal from water using a given mass. Action of the mass is based on water alkalizing. This type of interaction is also indicated by the size and direction of changes in the redox potential observed as a result of water contact with Hydrocleanit mass. The redox potential, and thus the oxidizing properties of the solution, decreased as a result of contact with a given mass.

\section{REFERENCES}

1. Anielak, A.M. 1998. Znaczenie potencjału elektrokinetycznego $\mathrm{w}$ fizykochemicznych procesach rozdziału faz. Mat. Sympozjum nt.: Oczyszczanie wody i ścieków oraz unieszkodliwianie odpadów. Politechnika Gdańska.

2. Anielak, A.M. \& Nowak, R. 2002. Influence of filtration bed building on microorganisms development from Siderrocapsaceae family in the process of manganese and iron removal from water. Environment Protection Engineering. 3(28), 27-40.

3. Apello, C.A.J. \& Postma, D. 2005. Geochemistry, groundwater and pollution. 2-nd edition. Leiden, London, New York, Philadelphia, Singapore. Balkema Publishers.

4. Barlokova, D. \& Ilavsky, J. 2010. Removal of iron and manganese from water using filtration by natural materials. Polish Journal of Environmental Studies. 19(6), 1117-1122.

5. Biedroń, I., Świderska-Bróż, M., Traczewska, T.M., Trusz-Zdybek, A. \& Wolska, M. 2013. Wpływ rodzaju materiału filtracyjnego na zmiany wartości wybranych wskaźników jakości wody podziemnej. Rocznik Ochrona Środowiska. 15, 845-862.

6. Dobrzyński, D. 2010. Badania potencjału redoks na przykładzie sudeckich wód leczniczych. Przegląd Geologiczny. 58(1), 46-53.

7. Drobnik, M. \& Latour, T. 2003. Badania wpływu procesów technologicznych w toku produkcyjnym wód butelkowanych na ich właściwości utleniająco-redukcyjne. Rocznik PZH. 54(3), 275-285.

8. James, Ch.N., Copeland, R.C. \& Lytle, D.A. 2014. Relationships between oxidation-reduction potential, oxidant, and $\mathrm{pH}$ in drinking water. AWWA Water Quality Technology Conference. San Antonio.

9. Jeż-Walkowiak, J., Dymaczewski, Z. \& Sozański, M. 2011. Parametry technologiczne procesu filtracji pospiesznej wód podziemnych przez złoża oksydacyjne i chemicznie nieaktywne. Inżynieria Ekologiczna. 26, 112-121.

10. Morgan, J. J. 2000. Manganese speciation and redox kinetics in natural waters. Manganese and its role in biological processes. Ed. Sigel A., Sigel H., Dekker M., New York, 1-34.

11. Nadaska, G., Lesny, J. \& Michalik, I. 2010. Environmental aspect of manganese chemistry. Hungarian Electronic Journal of Sciences, ENV100702-A. http://heja.szif.hu/ENV.

12. Nawrocki, J. 2010. Uzdatnianie wody. Procesy fizyczne, chemiczne i biologiczne. PWN Warszawa.

13. Nowak, R. 2013. Wpływ wybranych składników uzdatnianej wody na skuteczność jej odmanganiania w obecności mas aktywnych. Rocznik Ochrona Środowiska. 15, 25-50.

14. Ormanci, T., Turkoglu Demirkol, G., Aydın, I. \& Tufekci, N. 2013. An experimental study on manganese(II) removal with manganese dioxide recycling. Desalination and Water Treatment. 51, 2225-2230.

15. Peiffer, S. 2000. Characterization of the redox state of a aqueous systems: Towards a problem-oriented approach. Redox Fundamentals, Processes and Applications, M.H.W. Springer. Berlin, 24-41.

16. Piispanen, J.K. \& Sallanko, J.T. 2010. Mn(II) removal from groundwater with manganese oxidecoated filter media. Journal of Environmental Science and Health. 13(45), 1732-1740.

17. Scott, M.J. 1991. Kinetics of adsorption and redox processes on iron and manganese oxides: reactions of As (III) and Se(IV) at Goethite and birnessite surfaces. EQL REPORT. 33.

18. Skoczko, I., Piekutin, J. \& Ignatowicz, K. 2016. Efficiency of manganese removal from water in selected filter beds. Desalination and Water Treatment. 57(3), 1611-1619. 